Received: 09/04/2019

Revision: 04/12/2019

Accepted: 10/12/2019

OnlineFirst:01/02/2020

\title{
Potential of E-CoPAL Strategy to Improve Analytical Problem Solving and Teamwork Skills in Accounting Education
}

\section{Sri Sumaryati}

Postgraduate Student, Faculty of Teacher Training and Education, Universitas Sebelas Maret, Surakarta, Indonesia, srisumaryati@ staff.uns.ac.id

\section{Soetarno Joyoatmojo}

Prof., Faculty of Teacher Training and Education, Universitas Sebelas Maret, Surakarta, Indonesia,strn_jo@yahoo.co.id

\section{Sri Anitah Wiryawan}

Prof., Faculty of Teacher Training and Education Universitas Sebelas Maret, Surakarta, Indonesia,sri_anitah@yahoo.com

\section{Nunuk Suryani}

Prof., Faculty of Teacher Training and Education, Universitas Sebelas Maret, Surakarta, Indonesia, nunuksuryani@fkip.uns.ac.id

This study aims to examine the effect of E-CoPAL model implementation on analytical problem solving and teamwork skills. This research is a quasiexperimental research with a control group pretest-posttest in Accounting Education Program, Universitas Sebelas Maret, Surakarta, Indonesia in 2018/2019 academic year. The population in this study were all students taking the Educational Study Program as part of the Sebelas Maret University Accounting Education Study Program in Surakarta, Indonesia. The research sample comprised 72 students who were divided into class A (as an experimental group applying the E-CoPAL model) and class B (as a control group that was not treated).The data were obtained by using observation instruments which has analytical-problem solving and teamwork skills, and questionnaires expert validated and the certified senior lecturers in introductory accounting courses. The results show that the application of the E-CoPAL model was effective in improving analytical problemsolving and teamwork skills.

Keywords: analytical-problem solving skills, teamwork skills, collaborative learning, peer assisted learning, accounting education

Citation: Sumaryati, S., Joyoatmojo, S., Wiryawan, S. A., \& Suryani N. (2020). Potential of E-CoPAL Strategy to Improve Analytical Problem Solving and Teamwork Skills in Accounting Education. International Journal of Instruction, 13(2), 721-732. https://doi.org/10.29333/iji.2020.13249a 


\section{INTRODUCTION}

Increasing economic globalization, changes in technology challenges, business environment, increase litigation related to human resources, and changing needs about labor characteristics have forced an organization to increase its competitiveness. "Our people are our greatest resource" is one of the statements most often found in the company's annual report (Gupta, 2015). This indicates that the importance of maintaining the quality of human resources in an organization. Thus the success of every organization depends on the effective management of its people (Oke, 2015)

Quality human resources are those who have high competitive advantages, so that they can compete in job market. Referring to several researches, professionals expect graduates in accounting who have necessary skills needed by the industry and are ready to work as professionals (Low et al., 2016; Hussein, 2017). Presently, job providers are still complaining about the graduate's low generic skills, especially in analytical problem solving and teamwork (Politsinsky, Demenkova, \& Medvedeva, 2015). The low level in analytical-problem solving and teamwork skills becomes a problem not only in Indonesia, but on international level as well. Research by Mayangsari, E., Hermawan, M., \& Juwono, V. (2019); Collins et al., (2017); Suarta et al., (2015) in Indonesia, Norman, Latiff, \& Said, (2018) and Azmi, Hashim \& Yusoff, Y. M. (2018) in Malaysia, Webb \& Chaffer (2016) in Britain, Collins et al., (2015) in Taiwan and Vietnam proved that the low level of analytical-problem solving and teamwork skills has become a serious problem that needs to be solved.

Based on primary findings of the research by Abayadeera \& Watty (2016), the main reason of this gap is the in-optimality of learning in university in transferring skills needed by graduates, even though lecturers realize the high expectation of job provider of the graduates' skills. This necessitates Higher Education institutions to fix their curriculum to enable students develop their generic skills, especially analytical problem solving and teamwork skills.

Considering the learnable nature of these skills, efforts of internalization of these skills can be done through enhancement of learning quality from various courses, including accounting, among others. In the effort to improve analytical-problem solving and teamwork skills, teachers should notice the characteristics of the skill learning. First, skill learning in higher education is able to be conducted in various scientific disciplines and inherent in all learning material. This means that the skill teaching can be conducted in every courses corresponding to the courses' characters and features (Al-Alawneh, 2011). Second, its transferability is limited, meaning that not all attributes of the skills can be taught in one sitting of learning, so that the teacher should be able to determine what attribute of the skills that s/he would teach to the students through the learning. Third, the skills' attribute cannot be taught explicitly, so the teacher should be able to determine the appropriate strategy in transferring them in a learning process.

Based on the characteristics above, the teacher can provide varied interventions in learning, including intervention in learning models, learning media, and learning styles. To cite the opinion of Jääskelä, Nykänen \& Tynjälä (2018), one thing that teachers can 
do is combining collaborative learning model with peer tutoring strategy. In principle, collaborative learning model heavily emphasizes on a learning environment oriented towards teamwork, openness, audacity to argue, conduciveness, democracy, effectiveness, creativity, and fun atmosphere. In a well-built learning environment, the process of knowledge construction can be done in collaboration between individuals, and this situation can be adjusted by each individual through intellectual adaptation in socio-cultural context.

If this collaborative learning model, combined with peer-assisted learning model is properly and correctly applied, it can improve academic achievement, reduce the heavy workload of teachers, and develop skills desperately needed by students in the coming future Stigmar, 2016; Riese in Tarchi, Giuliana, \& Pinto, 2015). In addition, this strategy is believed to be able to cultivate other good values. For example, students acting as tutors will feel proud of their role and also learn from the experience. This will help to strengthen what they have learned and obtained from the responsibility. Moreover, students can be more able to conduct oral and written communication, to exchange opinion rationally, to learn delegate responsibilities to their team, and to do their responsibilities as well as possible (Raef et al., 2015) This is in accordance with the statement in Carr, et al., (2016) that "peer assisted learning can develop knowledge and skill through active help and support among status equals or matched companions."

\section{THEORETICAL BACKGROUND}

\section{Analytical - Problem solving skills}

Analytical and problem solving skills are defined by QAA for Higher Education (2015) as skills covering the ability to recognize certain events (for instance financial transaction) which are part of an accounting process, and the ability to classify accounting transaction that will underlie all financial records and reporting. In accordance with the nature and characteristics of accounting field, the culturing of these skills can make graduates own ability to obtain information, to filter and sort it out, to present it, and to evaluate it properly. For this to occur, an individual must be able to recognise the types of information needed, choose the sources and methods used appropriately, and be able to access the information needed effectively and efficiently. They are also required to critically evaluate information and sources, assimilate the selected information into their knowledge base, use the information effectively to achieve certain goals, and understand the economic, legal and social issues surrounding the use of information, in addition to accessing and using the information ethically and legally.

The statements above are supported by Ahadiat, N., \& Martin, R. M. (2015) that the need for students to develop attributes, preparations, and skills that accounting recruiters seek has placed a new pressure on educators and accounting students alike include that analytical skills is. Moreover, Grabowski (2019) concluded that three skills perceived by the graduates as crucial for successful progression in their career are generic rather than technical. The hierarchy of the most importance identified in the survey was the following is communication skills (verbal and written) and problem-solving skills. 


\section{Teamwork skill}

Teamwork skill is defined as the ability to effectively work together in a team. Several researchers identified that individuals having teamwork skill are portrayed as individuals who have ability to interact with their team members, are able to give and receive opinion to and from others in order to achieve common goal, able to motivate others in the team, able to settle conflicts inside the team, able to delegate tasks to others, and able and willing to lead the team (Paguio \& Jackling, 2016; Smith et al., 2015). Besides, the other components that are not less important in teamwork skill are the involvement of the aforementioned individuals in setting team goals, their ability to organize themselves and others in the team, and their ability in carrying out works tasked to the team (Volkov, A, \& Volkov, M., 2015). It is these interactions involving teamwork skill that will bring team synergy (Smith et al., 2015). meaning that the level of productivity of a group working as a team is greater than the combined levels of productivity of team members working individually.

\section{Electronic Collaborative Peer-Assisted Learning (E-CoPAL) Model}

Electronic Collaborative Peer-Assisted Learning (E-CoPAL) learning model is a new collaboration-based learning model developed based on various theories of learning, aiming at improving analytical-problem solving and teamwork skills in accounting course learning. In a Collaborative Learning (CL) environment, students are encouraged socially and emotionally to learn something from different perspectives, to be able to give opinions and defend their ideas, to exchange diverse ideas, to question other conceptual framework, and to be actively involved in learning processes. In order to be able to form an effective collaborative learning, Veldman, M. A., \& Kostons, D. (2019) explained that teachers should understand several elements forming collaborative learning: 1) Clearly perceived positive interdependence; 2) Considerable interaction; 3) Individual accountability and personal responsibility; 4) Social skills, and; 5) Group self-evaluation.

Clearly perceived positive interdependence makes each team member depends on each other in achieving goal. If there is a team member failing to do his/her job, all team members would bear the consequences. Members should believe that they are connected with others in the team and ensure that they would succeed together. The second element is considerable interaction. Here, each member helps and encourages each other to learn; explains things they have understood; collecting and sharing knowledge. Teamwork should be conducted interactively by giving mutual feedbacks, mutually practicing critical thinking, and most importantly, helping each other during learning process. In this element analytical skill, problem solving, and teamwork skill would be cultivated.

The next element is individual accountability and personal responsibility, which explain to teachers that in collaborative learning there exists individual responsibility. All students in the group are requested to be accountable in doing their own tasks, and to master all materials learned. Element of social skills means that in collaborative learning students are encouraged and helped to develop and practice their social skills, such as 
their ability to work in a team. In the group self-evaluation element, team members set group team, and periodically evaluate their individual performances as well as the team's overall performance, so that they can identify changes that occur to function more effectively.

In learning processes, the correct application of collaborative learning will give much positive impact which not only benefits teachers, but also the students as well, to be designated as a base in optimizing set learning objectives' achievement. Page (2017) summarized benefits of learning with CL model to four main categories, which are social, psychological, academic, and assessment. From social aspects, CL is believed to help students develop their social attitude and to build understanding of diversity between students and teachers. Students would realize that each individual in their group has different backgrounds, so that they are expected to develop tolerance and build a positive atmosphere of cooperation. In psychological aspects, CL centers learning at students which would improve their self-regard, reduce their anxiety, and develop positive attitude towards teacher.

Academically, CL would improve analytical skills and problem solving. Through active student involvement in learning process, it is believed that students will practice to conduct analysis to existing problems by using data and information obtained. This activity will give much positive learning experience to them, so that it is believed that their learning results can improve. In addition, through collaborative learning teachers can use various types of assessment, such as by using alternative assessment technique both in formative and summative assessments. This would give advantage to teachers and students in order to fix learning quality.

\section{Syntax of Electronic-Collaborative Peer Assisted Learning (E-CoPAL) Model}

E-CoPAL model is a product of development of learning model based on several theories such as constructivism theory of learning with collaborative learning component, social cognitive theory of learning, constructivism theory, behaviorism theory, and structural hierarchy theory. The theories became a part of consideration in developing steps, or syntaxes of learning, consisting of planning (divided into group information and planning for activities), facilitated session, repetition and feedback, and assessment. Constructivism theory bases the activities on the group information and planning for activities stages. At these stages lecturer delivers learning objectives and at the same time invites students to actively conduct knowledge orientation towards materials learned with daily life. Through this activity, students would understand more the importance of the material on accounting cycle in companies. In addition, learner would realize the importance of analytical-problem solving skills and teamwork skills to them. Social cognitive theory bases the stages of facilitated session and repetition and feedback. At these stages the students learn with their collaborative group with the help of tutors. This is in accordance with social cognitive theory that most of human behavior and their cognitive skills are learned through learning model, which in this case are the tutor and their peers. Additionally, students as learners are individuals in the Zone of Proximal Development (ZPD), which needs mentoring or scaffolding from others. Scaffolding is the act of providing some helps to students during the initial stages of 
learning, and then decreasing the help and giving opportunities to take over increasing responsibilities. Assistance in this context relates to the instructions and encouragement given to students to enable them to describe the problem in terms of the steps needed to solve it, combined with the provision of examples and other actions that will allow them to learn independently.

\begin{abstract}
Aim of Study
The current study seeks to investigate the effect of the E-CoPAL model in the topic on accounting cycle of service-companies classroom in raising up the analytical-problem solving and teamwork skills of students. The researchers assume that using diverse activities based on the E-CoPAL model may help these students to have a better analytical-problem solving and teamwork skills. The researchers expect that this study will benefit the curriculum designers, educational supervisors, and teaching staff, especially accounting teachers. Therefore, the study aims to answer the following research question: What is the effectiveness implementation of E-CoPAL model to improving analytical-problem solving and teamwork skills of students in learning the topic on accounting cycle of service-providing companies?
\end{abstract}

\title{
METHOD
}

\section{Research Design}

This research used the quasi-experiment research with pre-test-post-test control group design (Creswell, 2012). The research was conducted by applying Electronic Collaborative Peer-Assisted Learning (E-CoPAL) model in experiment class, while in the control class, the researcher used expository model commonly used by teachers in class. The data obtained were analyzed by using SPSS 22.0 for Windows to determine the results of descriptive analysis, and to conduct analysis recondition and ANCOVA tests.

\section{Population and Samples}

The population of the research comprised students of the Accounting Education Study Program, Faculty of Teacher Training and Education, Sebelas Maret University, Indonesia. The sample consisted of 72 students who were divided into two groups: an experimental group containing 42 students, and a control group containing 30 students. The experimental and control groups were randomly selected from 6 available classes.

\section{Research Instruments}

The data were obtained through observation with the aim of identifying the students' analytical problem-solving and teamwork skills, the indicators of which were developed according to QAA for Higher Education (2015). An instrument validity test was performed using the Pearson product-moment correlation test. Based on the results of the validity test, all of the indicators were declared valid. A reliability test using Cronbach's alpha delivered a value of 0.7935 , thus indicating that each item can be relied upon.

\section{FINDINGS}




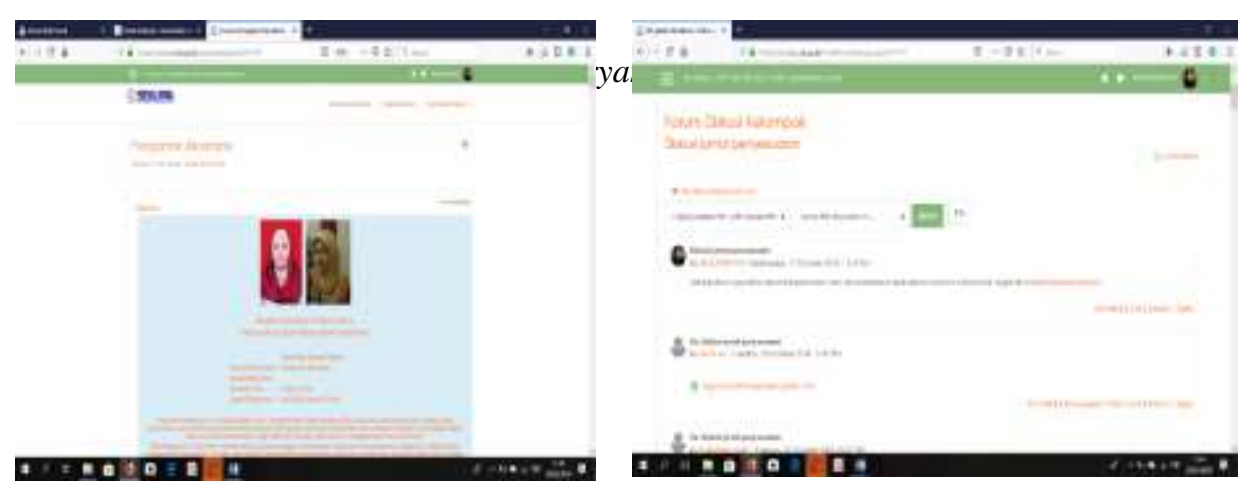

Figure 1

The Collaborative Peer-Assisted Learning Model-based Learning Web on the Topic of the Service Company's Accounting Cycle

The Collaborative Peer-Assisted Learning Model-based Learning Web

Referring to the explanations about E-CoPAL syntax, in the learning process lecturers and students can use learning websites developed by using collaborative approach. In this website, lecturers and students can use various facilities of learning sources, including video, electronic dictionary of accounting, concept map, e-books, and discussion forum as a means to complete accounting project collaboratively.

Descriptive Analysis Result of Pre-test and Post-test Scores of students' analyticalproblem solving and teamwork skills.

The Result of Descriptive Analysis of Pre-Test and Post-Test Scores of Students' Analytical-Problem Solving Skills of both experimental and existing classes are presented in Table $1 \& 2$.

Table 1

The Result of Descriptive Analysis of Pre- Test and Post- Test Scores of Students' Analytical-Problem Solving Skills

\begin{tabular}{clllll}
\hline Kinds of Test & Classes & Number of students & Min scores & Max scores & Mean \\
\hline Pre-Test & Experiment & 42 & 3 & 6,5 & 4,943 \\
& Existing & 35 & 4 & 6 & 5,071 \\
Post test & Experiment & 42 & 6 & 8,5 & 7,238 \\
& Existing & 35 & 6 & 10 & 6,871 \\
\hline
\end{tabular}

Table 2

The Result of Descriptive Analysis of Pre-test and Post-test Scores of Students' Teamwork Skills

\begin{tabular}{llllll}
\hline Kinds of Test & Classes & Number of students & Min scores & Max scores & Mean \\
\hline Pre-Test & Experiment & 42 & 6 & 11 & 8,238 \\
& Existing & 35 & 6 & 10.5 & 8,514 \\
\multirow{2}{*}{ Post test } & Experiment & 42 & 9 & 14 & 11,371 \\
& Existing & 35 & 9.5 & 12.5 & 11,131 \\
\hline
\end{tabular}

Referring to Tables 1 and 2 which show descriptive data of analytical-problem solving skills and teamwork skills, it can be understood that the increase of the average post-test score in the experiment class was greater than that in the control class. The value of the increase of analytical-problem solving skills in the experiment class was 2.295 while that in the control class amounted to 1.8. This also resulted in teamwork skills. The 
increase of value in the average teamwork skill post-test in experiment class was 3.133 while that in the control class amounted to 2.617.

\section{ANCOVA Analysis Result on students' analytical-problem solving and teamwork skills}

Analysis of Covariance (ANCOVA) was conducted to determine whether there was influence to students' analytical-problem solving and teamwork skills caused by the application of E-CoPAL model. Prior to the ANCOVA, the precondition tests namely: normality and homogeneity tests were conducted. The results of ANCOVA tests on the influence of E-CoPAL model application to students' analytical-problem solving and teamwork skills are shown in Tables 3 and 4 below.

Table 3

The Result of the ANCOVA on Students' Analytical-Problem Solving Skills

\begin{tabular}{llllll}
\hline Source & Type III Sum of Squares & df & Mean Square & F & Sig. \\
\hline Corrected Model & 19,700 & 2 & 9,850 & 27,311 & .000 \\
Intercept & 57,930 & 1 & 57,930 & 160,627 & .000 \\
Group & 12,077 & 1 & 12,077 & 33,485 & .000 \\
Pretest & 6,191 & 1 & 6,191 & 17.166 & .000 \\
Error & 25,967 & 72 & .361 & & \\
Total & $3,651,000$ & 75 & & & \\
Corrected Total & 45,667 & 74 & & & \\
\hline
\end{tabular}

Table 4

The Result of the ANCOVA on Students' Teamwork Skills

\begin{tabular}{llllll}
\hline Source & Type III Sum of Squares & df & Mean Square & F & Sig. \\
\hline Corrected Model & 97,825 & 2 & 48,913 & 64,975 & .000 \\
Intercept & 68,523 & 1 & 68,523 & 91,024 & .000 \\
Group & 94,786 & 1 & 94,786 & 125,912 & .000 \\
Pretest & 8,794 & 1 & 8,794 & 11,682 & .001 \\
Error & 55,707 & 74 & .753 & & \\
Total & 8085,250 & 77 & & & \\
Corrected Total & 153,532 & 76 & & & \\
\hline
\end{tabular}

Referring to Tables 3 and 4, it is shown that the results of the ANCOVA (F arithmetic) on the students' analytical problem-solving skills amounted to 33.485 with a significance of 0.000. Meanwhile, the results of the ANCOVA (F arithmetic) on teamwork skills amounted to 125.912 with a significance of 0.000 . Based on these results, the application of the E-CoPAL model was effective in improving analytical problem-solving and teamwork skills.

\section{DISCUSSION}

Tables 1 and 2 show that the value of the increase of average post-test scores of two skills in experiment class were greater than that in the control class. The value of increase of analytical-problem solving skill and teamwork skill in experiment class were greater than that in the control class. Furthermore, Tables 3 and 4 show that the application of Electronic Collaborative Peer-Assisted Learning (E-CoPAL) model on the topic of accounting cycle of service-providing companies had the potential to improve analytical-problem solving and teamwork skills. 
The above results have proven that E-CoPAL model is one of potential strategies in order to improve students' analytical-problem solving and teamwork skills. Syntax of ECoPAL model on the topic of accounting cycle of service-providing companies consisting of 5 stages: planning-group information, planning for activities, facilitated session, repetition and feedback, and assessment has helped lecturers and students to improve their analytical-problem solving and teamwork skills. At the stages of group information and planning for activities, lecturer delivers learning objectives and at the same time invites students to actively conduct knowledge orientation towards materials learned with daily life. Through this activity, students would understand better the importance of the material on accounting cycle in companies. In addition, learners would realize the importance of analytical-problem solving skills and teamwork skills. At these stages also the students are accustomed to obtaining various types of information in order to finish their assignments.

The next stage is facilitated session. At this stage, the learning activities in collaborative groups by using peer-assisted learning strategy took place. Here, lecturers facilitated/guided students to achieve expected competence. Help provided in this way were guides and encouragement to elaborate problems into steps of solution, providing examples, and other acts that enables students to learn how to do things independently. This scaffolding process gradually decreases when students achieve expected competence (Barrouillet, 2015). Moreover, this activity based itself on the presumption that students as learners are individuals in the Zone of Proximal Development (ZPD). This zone is the distance between the real development level, defined as the ability of independent problem solving, and potential development level, defined as the ability of problem solving under guidance of adults or through cooperation with more able peers. At this stage, analytical-problem solving and teamwork skills would be well built, with the indication that each student had chances to interact and express ideas to solve accounting cases published in the learning website. This activity could be conducted by face-to-face meeting or online. Besides, while solving cases of accounting of serviceproviding companies, each collaborative group could filter and sort out types of information needed through learning sources provided in the learning website.

The subsequent syntax was repetition and feedback. As in facilitated session stage, at this stage students were given opportunities to have a lot of practice in order to improve their accounting competence. Here, the students with their collaborative groups solve accounting cases of service-providing companies in simple ways. Students would practice analyzing proofs of transaction, compiling transaction journal, conducting posting, adjusting journal entry, compiling worksheet, to compiling complete financial report to the accounting project of a service-providing company provided in the learning website. Hence, the more often the students read or repeat materials learned, the more knowledgeable they become (Pritchard, 2017). In addition to increasing understanding of accounting, good habituation would also certainly foster good analytical-problem solving and teamwork skills.

The last stage of E-CoPAL model is assessment. At this stage students would conduct self and peer assessment to analytical-problem solving and teamwork skills acquired by 
using assessment instruments. Here, students are trained to conduct self-reflection about the skills cultivated through learning process by using E-CoPAL model. At this point, cultivation of student activities related to prevailing moral values, internalization of scientific attitudes, and appreciation of the greatness of Allah SWT occurred (Saputri, Sajidan., Rinanto, \& Afandi, 2019.). Syntax of self-reflection developed in E-CoPAL model is the important step which can direct a person to have better self-regulation. Students having better self-regulation would be able to achieve better learning results and have high learning motivation (Al-Rawahi \& Al-balushi, 2015; Daniela, 2015; Sridharan \& Boud, 2019). The syntax of self-reflection is based on Dewey's theory of reflective thinking (Dimova \& Kamarska, 2015) and Marzano's ideas about the habit of the mind exercising aspects of self-regulation to encourage students to know how effective the learning process is for them (Marzano \& Pickering, 2006).

\section{CONCLUSION}

The Electronic-Collaborative Peer Assisted Learning model applied on the topic of accounting cycle of a service-providing company is proven to be effective in improving students' analytical-problem solving skills and teamwork skills. The effectiveness of ECoPAL model can be seen by the results of analysis of covariance.

This research is limited to the topic of the service company accounting cycle and would be more interesting if it could be applied to other subject matter in the accounting family conducted at various levels. It is also limited to the effectiveness of the E-CoPAL model in empowering students' analytical problem-solving skills and teamwork skills. Thus, future studies may seek to enrich the way in which this model is integrated with other activities in learning so as to improve other generic skills.

\section{ACKNOWLEDGMENTS}

The researcher would like to thank LPPM (Development and Community Service Institution) of Sebelas Maret University for funding this research with PNBP Fund with contract No.543/UN 27.21/PP/2018.

\section{REFERENCES}

Abayadeera, N., \& Watty, K. (2016). Generic skills in accounting education in a developing country: exploratory evidence from Sri Lanka. Asian Review of Accounting, 24(2), 149-170.

Ahadiat, N., \& Martin, R. M. (2015). Attributes, preparations, and skills accounting professionals seek in college graduates for entry-level positions vs. promotion. Journal of Business and Accounting, 8(1), 179.

Al-Alawneh \& Muhammad, K. (2011). Vocational education graduates' generic skills as perceived by educators and employers in Jordan labor market. The IUP Journal of Soft Skills, V(2), 7-20

Al-Rawahi, N. M., \& Al-Balushi, S. M. (2015). The effect of reflective science journal writing on students' self-regulated learning strategies. International Journal of Environmental and Science Education, 10(3), 367-379. 
Azmi, I. A. G., Hashim, R. C., \& Yusoff, Y. M. (2018). The employability skills of Malaysian university students. Int. J. of Modern Trends in Social Sciences, 1(3), 1-14.

Barrouillet, P. (2015). Theories of cognitive development: From Piaget to today. Developmental Review 38, 1-12

Carr, W. D., Volberding, J., \& Vardiman, P. (2011). A peer-assisted learning program and its effect on student skill demonstration. Athletic Training Edu. J, 6(3), 129-135

Collins, N., Chou, Y. M., Warner, M., \& Rowley, C. (2017). Human factors in East Asian virtual teamwork: A comparative study of Indonesia, Taiwan and Vietnam. The International Journal of Human Resource Management, 28(10), 1475-1498.

Creswell, J. W. (2012). Educational research: Planning, conducting, and evaluating quantitative and qualitative research. Boston, MA: Pearson

Daniela, P. (2015). The relationship between self-regulation, motivation and performance at secondary school students. Proc-Soc and Beha. Sci, 191, 2549-2553.

Dimova, Y., \& Kamarska, K. (2015). Rediscovering John Dewey's model of learning through reflective inquiry. Problems of Education in the 21st Century, 63, 29-39.

Grabowski, R. (2019). Journal of Management and Financial Sciences, XII (36), 123138

Gupta, M., (2015). Strategic human resource management: Source of competitive advantage. PARIPEX-Indian Journal of Research, 4(7), 172-173.

Hussein, A. (2017). Importance of generic skills in accounting education: Evidence from Egypt. International Journal of Accounting and Financial Reporting, 7(2), 16-35.

Jääskelä, P., Nykänen, S., \& Tynjälä, P. (2018). Models for the development of generic skills in Finnish higher education. J. of Further and Higher Education, 42(1), 130-142.

Low, M., Botes, V., De La Rue, D., \& Allen, J. (2016). Accounting employers' expectations-the ideal accounting graduates. J. of Bus. Edu. \& Sc. of Teac, 10(1), 36-57.

Marzano, R. J., \& Pickering, D. J. (2006). Dimension of Learning, teaching manual. Hawker Brownlow Education

Mayangsari, E., Hermawan, M., \& Juwono, V. (2019). Indonesian accounting professionals and ASEAN's mutual recognition arrangement; An exploratory study of employability factors. Retrieved from https://eudl.eu/proceedings/WoMELA-GG/2019

Norman, S. N., Latiff, A. R. A., \& Said, R. M. (2018). Employers' perception on skill competencies and the actual performance of bachelor of accounting graduates in Malaysia. Management, 5(3), 88-95.

Oke, L. (2016). Human resources management. IJHCS, 1(4), 376-387.

Page, A. (2017). Implementing cooperative learning: A consideration of barriers and enablers. Journal of Initial Teacher Inquiry, 3(49), 49-52.

Paguio, R., \& Jackling, B. (2016), Teamwork from accounting graduates: what do employers really expect? Accounting Research Journal, 29(3), 348-366. 
Politsinsky, E., Demenkova, L., \& Medvedeva, O. (2015). Ways of students training aimed at analytical skills development while solving learning tasks. Procedia-Social and Behavioral Sciences, 206, 383-387.

Pritchard, A. (2017). Ways of learning: Learning theories for the classroom. Routledge. Quality Assurance Agency for Higher Education (QAA). (2015). UK quality code for higher education. The quality assurance agency for higher education, Gloucester. Retrieved from http://www.qaa.ac.uk/.

Raef A. Lawson, Edward J. Blocher, Peter C. Brewer, Jan Taylor Morris, Kevin D. Stocks, James E. Sorensen, David E. Stout, \& Marc J. F. Wouters (2015) Thoughts on competency integration in accounting education. Issues in Acco. Edu, 30(3),149-171.

Saputri, A. C. (2019). Improving students' critical thinking skills in cell-metabolism learning using stimulating higher order thinking skills model. International Journal of Instruction, 12(1), 327-342.

Smith, S., Farra, S., Ten Eyck, R., \& Bashaw, M. (2015). Development of an instrument to measure nursing student teamwork skills. Clin. Simul. in Nursing, 11(12), 507-512.

Sridharan, B., \& Boud, D. (2019). The effects of peer judgements on teamwork and selfassessment ability in collaborative group work. Assessment \& Evaluation in Higher Education, 44(6), 894-909.

Stigmar, M. (2016). Peer-to-peer teaching in higher education: A critical literature review. Mentoring \& Tutoring: Partnership in Learning, 24(2), 124-136.

Suarta, I. M., Hardika, N. S., Sanjaya, I. G. N., \& Arjana, I. W. B. (2015). Model authentic self-assessment dalam pengembangan employability skills mahasiswa pendidikan tinggi vokasi. Jurnal Penelitian dan Evaluasi Pendidikan, 19(1), 46-57.

Tarchi, C., \& Pinto, G. (2015). Educational practices and peer-assisted learning: analyzing students' interactive dynamics in a joint drawing task. Social Psychology of Education, 18(2), 393-409.

Tynjälä, P., Virtanen, A., Klemola, U., Kostiainen, E., \& Rasku-Puttonen, H. (2016). Developing social competence and other generic skills in teacher education: applying the model of integrative pedagogy. European J. of Teacher Education, 39(3), 368-387.

Veldman, M. A., \& Kostons, D. (2019). Cooperative and collaborative learning: considering four dimensions of learning in groups. Pedagogische Studien, 96(2), 76-81.

Volkov, A., \& Volkov, M. (2015). Teamwork benefits in tertiary education: Student perceptions that lead to best practice assessment design. Edu \& Trai., 57(3), 262-278.

Watts, H., Malliris, M., \& Billingham, O. (2015). Online peer assisted learning: reporting on practice. Journal of Peer learning, 8(8), 85-104.

Webb, J., \& Chaffer, C. (2016). The expectation performance gap in accounting education: A review of generic skills development in UK accounting degrees. Accounting Education, 25(4), 349-367. 